\title{
ALBERTO BARRÓN RUIZ DE LA CUESTA, Los seviros augustales en Hispania y las Galias. Una aproximación a la movilidad social en el Imperio Romano, Universidad de La Rioja, Logroño, 2020.
}

¿Qué ocurre cuando las circunstancias sociales impiden al individuo desarrollar todo su potencial? ¿Cuándo lograr un papel destacado en la vida religiosa, política e institucional no depende tanto de los méritos propios, como de las reglas impuestas por aquellos que dominan las vías de promoción social?

Son dos de las cuestiones que el libro de Alberto Barrón Ruiz de la Cuesta plantea con la intención de mostrar desde diferentes ángulos los fundamentos de una antigua institución social romana, el sevirato augustal. Una vía de promoción a la que accedían los libertos enriquecidos, que por su origen servil no podían acceder de otro modo a un plano más elevado en la escala social.

El autor afronta con originalidad su estudio y establece como base el análisis de más de seiscientas inscripciones halladas en Hispania y las Galias, con el objetivo de mostrar los fundamentos de dicha institución, en un territorio que considera representativo de la vida económica y social del occidente europeo principalmente durante los s. I y III d.C.

Su primera tarea será la de establecer sus vínculos con el culto imperial, las funciones cívicas asociadas al cargo y su vinculación directa con el desarrollo de la vida económica y social de las ciudades. Analiza también las motivaciones de los libertos ricos para acceder al cargo, y como el ordo decuriorum, la élite dirigente de las ciudades llegó a controlarlos hasta convertirlos en una segunda élite local con el beneplácito del poder imperial.

Un relato en el que se detallan los privilegios de aquellos que aspiraban a formar parte del nuevo ordo, se establece su vinculación con la religión tradicional romana, y se analizan las fuentes literarias y epigráficas utilizadas para llevar a cabo este trabajo. Un texto en el que también se estudia el origen, la evolución y el alcance de dicha institución a través de los estudios históricos que desde finales del s. XIX hasta la actualidad trataron de arrojar luz sobre el sevirato augustal.

La investigación asimismo considera la desigual distribución territorial de los testimonios epigráficos y concluye que su desarrollo, además de depender 
de la situación geográfica de las ciudades obedecía a las iniciativas locales que lograron adaptarla a sus necesidades. Profundiza además en el origen de aquellos que formaron parte de ella y concluye que eran en su mayor parte libertos que solo contaban con el sevirato como vía de ascenso social y reconocimiento público en dichos enclaves.

Estudia su funcionamiento y señala que los honores y distinciones que alcanzaron los augustales, aunque no tuvieron transcendencia en la vida urbana ni reconocimiento oficial sí que ayudaron a mejorar el funcionamiento de las ciudades. El pago de la suma honoraria, o el ejercicio de diversas everguesias, daban a este colectivo un carácter semioficial además de prestigio social.

Donaciones de diversa índole que incluían los espectáculos y edificios públicos, las distribuciones en dinero o en especie, o los banquetes y que tenían como objetivo reforzar el espíritu comunitario. Obsequios vinculados al ámbito religioso, o al ejercicio de la magistratura destinados a incrementar el prestigio del donante y colocarlo en el centro de atención remarcando su posición dentro de la jerarquía social de las ciudades.

Ofrece en definitiva una imagen cercana y detallada de su funcionamiento e incide en la importancia que tuvieron en el desarrollo urbano de una sociedad que los necesitaba para garantizar el desarrollo económico y social de sus territorios. También en el dinamismo de sus miembros que disponían de amplias redes de comunicación y de comercio circunstancias que los convertían, a pesar de todo, en un colectivo social privilegiado durante el Imperio romano.

María Silas García Conde

Instituto de Estudios Riojanos

silasgarciaconde@me.com 